\title{
Invasion inhibition effects and immunogenicity after vaccination of SPF chicks with a Salmonella Enteritidis live vaccine
}

\section{Nachweis von Invasionshemmeffekten und der Immunogenität nach Impfung von SPF-Küken mit einer Salmonella-Enteritidis- Lebendvakzine}

Authors

Sven Springer ${ }^{1}$, Tobias Theuß ${ }^{1}$, Imre Toth², Zsuzsanna Szogyenyi ${ }^{2}$

\section{(c) $\$ \cong$}

Institutes

1 Ceva Innovation Center GmbH, Dessau-Roßlau, Germany

2 Ceva Phylaxia Veterinary Biologicals co. Ltd, Budapest, Hungary

\section{Schlüsselwörter}

Immunantwort, Salmonella Typhimurium, monophasisch, Phagentyp, Infektionsmodell, Serologie

Key words

Immune response, Salmonella Typhimurium, monophasic, phage type, challenge model, serology

received 20.11.2020

accepted $\quad 07.05 .2021$

Bibliography

Tierarztl Prax Ausg G Grosstiere Nutztiere 2021; 49: 249-255

DOI 10.1055/a-1520-1369

ISSN 1434-1220

(c) 2021. The Author(s).

This is an open access article published by Thieme under the terms of the Creative Commons Attribution-NonDerivative-NonCommercial-License, permitting copying and reproduction so long as the original work is given appropriate credit. Contents may not be used for commercial purposes, or adapted, remixed, transformed or built upon. (https://creativecommons.org/licenses/by-nc-nd/4.0/)

Georg Thieme Verlag KG, Rüdigerstraße 14,

70469 Stuttgart, Germany

Correspondence address

Dr. Sven Springer

Ceva Innovation Center GmbH

Am Pharmapark

06861 Dessau-Roßlau

Deutschland

sven.springer@ceva.com

\section{ZUSAMMENFASSUNG}

Gegenstand und Ziel Für den Eintrag von Salmonellen in die Lebensmittelkette des Menschen haben Infektionen der Hühner mit Salmonella Enteritidis, Salmonella Typhimurium und Salmonella Infantis große Bedeutung. Zur Bekämpfung von Infektionen werden, zusätzlich zu veterinärhygienischen Maßnahmen, inaktivierte Impfstoffe und Lebendimpfstoffe auf der Basis attenuierter Impfstämme eingesetzt. Neben einer adaptiven Immunantwort induzieren bestimmte Impfstämme angeborene Immunmechanismen, die eine Invasion des Erregers in innere Organe verhindern bzw. behindern. Es ist ungeklärt, ob sich diese Hemmungseffekte auch gegen andere Salmonella-Serovare richten. Weiterhin ist nicht bekannt, ob sich die adaptive Immunantwort nach Impfung mit einem Salmonella-Enteritidis-Phagentyp-4-Lebendimpfstoff auch auf andere Lysotypen von Salmonella Enteritidis und Typhimurium erstreckt.

Material und Methode Eintagsküken wurden mit einer Salmonella-Enteritidis-Lebendvakzine oral vakziniert. Zur Prüfung des Auftretens der Invasionshemmung wurden die Tiere am Tag darauf mit einem markierten Salmonella-Typhimurium- bzw. Salmonella-Infantis-Stamm infiziert. Zum Nachweis der adaptiven Immunantwort erfolgte nach der Impfung eine orale Infektionsbelastung mit markierten SalmonellaEnteritidis-Stämmen der Phagetypen 1, 8 und 21 am 63., 42. und 51. Lebenstag sowie einem monophasischen SalmonellaTyphimurium-Stamm („Definitive Type“ 193) am 17. Lebenstag. Nach der Infektion wurde zu verschiedenen Zeitpunkten der Infektionsstammgehalt in Leber und Blinddarmgewebe ermittelt und mit den Werten einer nicht geimpften Kontrollgruppe verglichen.

Ergebnisse Die Impfung mit dem Salmonella-EnteritidisLebendimpfstoff führte zu einer signifikanten Reduzierung der Invasion in die Blinddarmschleimhaut und Leber nach früher Infektion mit Salmonella Typhimurium und Salmonella Infantis. Weiterhin induzierte die Impfung eine adaptive Immunität gegen die getesteten „Non-Phagentyp-4“-Salmonella-EnteritidisStämme und den monophasischen Salmonella-TyphimuriumStamm. 
Schlussfolgerung und klinische Relevanz Die Ergebnisse der Studie zeigen, dass eine Impfung mit dem SalmonellaEnteritidis-Phagentyp-4-Lebendimpfstoff eine frühe systemische Invasion mit Salmonella Typhimurium und Salmonella Infantis behindert. Gleichzeitig war eine adaptive Immunantwort gegen Salmonella-Enteritidis-Stämme, die nicht zum Phagentyp 4 gehören, und einen monophasischen Salmonella Typhimurium-Stamm nachweisbar.

\section{ABSTRACT}

Objective Meat and eggs from chickens infected with Salmonella Enteritidis, Salmonella Typhimurium and Salmonella Infantis are considered to be an important source of Salmonella infections for humans. In order to control Salmonella infections in chickens, basic biosecurity measures are taken in combination with inactivated or attenuated live vaccines. Apart from an adaptive immune response, some live vaccines also induce innate immune mechanisms that prevent or inhibit systemic invasion with homologous Salmonella serovars. It is unknown whether these invasion inhibition effects are also directed against heterologous Salmonella serovars. Furthermore, it is unclear whether the adaptive immune response after vaccination with a Salmonella Enteritidis phage type 4 live vaccine is also directed against other phage types of Salmonella Enteritidis and Typhimurium.
Material and methods Specific pathogen-free day-old chicks were vaccinated orally with a commercially available Salmonella Enteritidis live vaccine. To test the invasion inhibition effect, the animals were challenged orally with a labelled Salmonella Typhimurium or Salmonella Infantis strain 1 day after vaccination. To demonstrate the adaptive immune response against non-phage type 4 Salmonella Enteritidis strains and a monophasic Salmonella Typhimurium strain, the chickens were challenged with Salmonella Enteritidis strains of phage types 1, 8 and 21 and monophasic Salmonella Typhimurium strain (Definitive Type 193). After challenge, the abundance of the challenge strain in liver and cecal tissue was enumerated and compared with a corresponding control group.

Results Findings showed that the live Salmonella Enteritidis vaccine inhibits systemic invasion after early infection with Salmonella Typhimurium and Salmonella Infantis. Furthermore, adaptive immunity against the tested non-phage type 4 Salmonella Enteritidis strains and the monophasic Salmonella Typhimurium strain was demonstrated.

Conclusion and clinical relevance The results of this study demonstrate that vaccination with the Salmonella Enteritidis phage type 4 live vaccine significantly inhibits the invasion of Salmonella Typhimurium and Infantis. Furthermore, an adaptive immune response was also detected against non-phage type 4 Salmonella Enteritidis strains and a monophasic Salmonella Typhimurium strain.

\section{Introduction}

Despite intensive control measures to reduce Salmonella infection in poultry and humans in the last decades, 91857 confirmed cases of salmonellosis in humans were reported in the EU countries in 2018 [1]. Although the prevalence of Salmonella in eggs and egg products has been markedly reduced, these are still the most common causes of Salmonella cases in humans. The 3 most commonly reported Salmonella serovars in humans were Salmonella (S.) Enteritidis, S. Typhimurium and monophasic S. Typhimurium $(1,4,[5], 12: i:-)$. S. Infantis was reported as the fourth most common serovar usually associated with broiler meat [1].

Historically, human infections with S. Enteritidis were predominantly phage type (PT) 4 [2]. However, other phage types like PT1, PT8, PT14b and PT21 (non-PT4 strains) have played an important role [2][3], as well.

In addition to hygiene measures at all levels of production, live attenuated and inactivated vaccines against $S$. Enteritidis and S. Typhimurium have proven to be effective in chicken flocks for many years. It is generally accepted that live attenuated vaccines are not only easier to administer but are also more effective due to the induction of local, humoral, and cell-mediated immune mechanisms [4].

Live vaccines are able to induce both an innate and an adaptive immune response. Braukmann et al. [5] were the first to show inhibition of the systemic invasion of a virulent $S$. Enteritidis strain (innate immunity) just 2 days after vaccination with a commercially available attenuated S. Enteritidis live vaccine (SE-LV). In contrast, the occurrence of an adaptive immune response has been shown several times for different vaccines by different authors [6][7][8] [9][10].

The aim of our study was to test whether the homologous invasion-inhibition effect described for the SE-LV [5] can also be demonstrated against other serovars (S. Typhimurium and S. Infantis). In addition, we examined whether the SE-LV based on PT4 also induces immunogenicity against other non-PT4 strains and a monophasic S. Typhimurium strain.

\section{Materials and methods}

\section{Chickens}

Specific pathogen-free day-old White Leghorn chicks were hatched from eggs, which were obtained from VALO BioMedia $\mathrm{GmbH}$ (Osterholz-Scharmbeck, Germany). The vaccinated and control groups were kept in cages in separate rooms to avoid the spread of the vaccine strain to the control groups. During the rearing period, commercial feed for hens without feed additives (ssniff Special diets $\mathrm{GmbH}$, Soest, Germany) and drinking water were available ad libitum. The experiments were performed in accordance with the German law of animal welfare (registration number IDT-A042-2015).

\section{Bacterial strains and culture}

Vaccine strain

In all trials, SPF chickens were orally vaccinated using a buttoned cannula with the minimum effective dose $\left(1 \times 10^{8} \mathrm{cfu}\right.$ per animal) 
- Table 1 Study design for testing of the invasion inhibition effect (number of animals, vaccination, challenge, and necropsy dates).

- Tab. 1 Versuchsaufbau zur Prüfung des Invasionshemmungseffekts (Anzahl der Tiere, Zeitpunkte der Impfung, der Infektion und der Sektion der Tiere).

\begin{tabular}{|c|c|c|c|c|c|}
\hline Trial & Group & Animals (n) & Vaccination & Challenge & $\begin{array}{l}\text { Quantitative determination } \\
\text { of challenge bacteria }\end{array}$ \\
\hline \multirow[t]{2}{*}{1} & Vaccinated & 12 & Day 1 & \multirow[t]{2}{*}{ Day $2(\mathrm{STm}) 5 \times 10^{5} \mathrm{cfu} /$ chicken } & \multirow[t]{2}{*}{ Days 6 and 10} \\
\hline & Control & 12 & - & & \\
\hline \multirow[t]{2}{*}{2} & Vaccinated & 12 & Day 1 & \multirow[t]{2}{*}{ Day 2 (SI) $5 \times 10^{4} \mathrm{cfu} /$ chicken } & \multirow[t]{2}{*}{ Days 6 and 9} \\
\hline & Control & 12 & - & & \\
\hline
\end{tabular}

- Table 2 Study design for testing the immunogenicity against non-PT4 S. Enteritidis strains and a monophasic S. Typhimurium strain (number of animals, vaccination, challenge and necropsy dates).

-Tab. 2 Versuchsaufbau zur Prüfung der Immunogenität gegen “Non-PT4”-S. Enteritidis-Stämme und einen monophasischen S.-TyphimuriumStamm (Anzahl der Tiere, Zeitpunkte der Impfung, Infektion und Sektion der Tiere).

\begin{tabular}{|c|c|c|c|c|c|}
\hline Trial & Group & Animals ( $\mathrm{n}$ ) & Vaccination & Challenge & $\begin{array}{l}\text { Quantitative determination } \\
\text { of challenge bacteria }\end{array}$ \\
\hline \multirow[t]{2}{*}{3} & Vaccinated & 8 & Days 2 and 15 & \multirow[t]{2}{*}{ Day 42 (SE PT8) $1 \times 10^{9} \mathrm{cfu} /$ chicken } & \multirow[t]{2}{*}{ Day 49} \\
\hline & Control & 8 & - & & \\
\hline \multirow[t]{2}{*}{4} & Vaccinated & 8 & Days 2 and 15 & \multirow[t]{2}{*}{ Day 51 (SE PT21) $1 \times 10^{9} \mathrm{cfu} /$ chicken } & \multirow[t]{2}{*}{ Day 58} \\
\hline & Control & 8 & - & & \\
\hline \multirow[t]{2}{*}{5} & Vaccinated & 8 & Days 2 and 15 & \multirow[t]{2}{*}{ Day 63 (SE PT1) $1 \times 10^{9} \mathrm{cfu} /$ chicken } & \multirow[t]{2}{*}{ Day 70} \\
\hline & Control & 8 & - & & \\
\hline \multirow[t]{2}{*}{6} & Vaccinated & 16 & Day 1 & \multirow[t]{2}{*}{ Day $17(\mathrm{mSTm}) 1 \times 10^{9} \mathrm{cfu} /$ chicken } & \multirow[t]{2}{*}{ Days 24 and 31} \\
\hline & Control & 16 & - & & \\
\hline
\end{tabular}

of the attenuated and auxotrophic (adenine, histidine) S. Enteritidis PT4 strain no. 441/114 (Salmovac 440 [Salmovac SE], Ceva Santé Animale, Libourne, France) (SE-LV).

\section{Challenge strains}

To examine the heterologous invasion inhibition effect of the SELV, a nalidixic acid resistant S. Typhimurium strain Definitive Type (DT) 204 (FLI no. 421) and a multidrug-resistant S. Infantis strain (RKI no. 12-2357) were used.

The immunogenicity of the SE-LV against certain non-PT4 strains was examined by using spontaneously occurring nalidixic acid resistant S. Enteritidis strains: PT1 (RKI no. 06-7328), PT8 (RKI no. 04-7681) and PT21 (RKI no. 04-2049).

The monophasic S. Typhimurium strain (4,[5],12:i:-) DT 193 resistant to ampicillin, streptomycin, sulfamerazine, and oxytetracycline was used to demonstrate cross immunogenicity of the SE-LV against a monophasic S. Typhimurium strain. This strain was described in detail by Trüpschuch et al. [11].

Cultivation of the infection strains was carried out over 2 pre-cultures in STM 6/83 Medium (IDT Biologika GmbH, Dessau-Rosslau,
Germany). After cultivation the strains were washed, concentrated and stored at $-20^{\circ} \mathrm{C}$ until use.

\section{Experimental design}

All trials were designed as randomized, blinded and controlled studies.

\section{Invasion inhibition trials}

A total of 12 day-old chicks per group were vaccinated orally with the SE-LV at day 1 of age. A corresponding control group remained unvaccinated ( $\triangleright$ Table 1 ). On day 2 of age the chickens were challenged orally at a dose of $5 \times 10^{5} \mathrm{cfu}$ S. Typhimurium no. $421 /$ bird or at a dose of $5 \times 10^{4} \mathrm{cfu} S$. Infantis no. 12-2357/bird using a buttoned cannula. On days 6 and 9 (10) of age, the animals were euthanized and the number of challenge strain bacteria in liver and cecal tissue (complete cecum without ingesta) was determined.

\section{Immunogenicity trials}

For testing of the immunogenicity against S. Enteritidis non-PT4 strains 8 birds/group were vaccinated orally with the SE-LV on days 
- Table 3 Challenge strain content (mean $\log 10 \mathrm{cfu} / \mathrm{g}$ ) in liver and cecal tissue after challenge (testing of the invasion inhibition effect).

- Tab. 3 Infektionsstammgehalte in Leber und Blinddarmgewebe nach der Infektion (Prüfung des Invasionshemmungseffekts).

\begin{tabular}{|c|c|c|c|c|c|}
\hline \multirow[t]{2}{*}{ Trial } & \multirow[t]{2}{*}{ Group } & \multirow{2}{*}{$\begin{array}{l}\text { Challenge } \\
\text { strain }\end{array}$} & \multirow{2}{*}{$\begin{array}{l}\text { Day post } \\
\text { challenge }\end{array}$} & \multicolumn{2}{|c|}{ Challenge strain content (mean \pm SD) in $\log _{10} \mathrm{cfu} / \mathrm{g}$} \\
\hline & & & & Liver & Cecal tissue \\
\hline \multirow[t]{4}{*}{1} & Vaccinated & \multirow[t]{4}{*}{ STm } & 4 & 0 & $4.72 \pm 2.17^{\mathrm{a}}$ \\
\hline & Control & & 4 & $1.09 \pm 1.74$ & $6.84 \pm 1.32$ \\
\hline & Vaccinated & & 8 & $0^{\text {a }}$ & $4.90 \pm 0.87^{a}$ \\
\hline & Control & & 8 & $2.30 \pm 0.76$ & $7.24 \pm 0.59$ \\
\hline \multirow[t]{4}{*}{2} & Vaccinated & \multirow[t]{4}{*}{ SI } & 4 & 0 & $6.63 \pm 0.45^{\mathrm{a}}$ \\
\hline & Control & & 4 & $0.43 \pm 0.78$ & $7.72 \pm 0.60$ \\
\hline & Vaccinated & & 7 & $0^{\mathrm{a}}$ & $4.48 \pm 0.45^{a}$ \\
\hline & Control & & 7 & $0.67 \pm 0.67$ & $7.27 \pm 0.17$ \\
\hline
\end{tabular}

2 and 15 of age. Corresponding control groups were not vaccinated ( Table 2 ). Both the vaccinated and non-vaccinated control groups were challenged orally using a buttoned cannula with S. Enteritidis PT8 on day 42, with S. Enteritidis PT21 on day 51 and with S. Enteritidis PT1 on day 63 of age. The infection dose was $1 \times 10^{9} \mathrm{cfu}$ per animal. The animals were stunned by head impact followed by exsanguination 7 days (trials 3-5) post challenge (dpc). Liver and cecal mucosa were taken from each animal for determination of the number of the challenge strain bacteria. Blood samples were taken for serological testing for antibodies against $S$. Enteritidis on the day of challenge and necropsy, respectively.

To prove the immunogenicity against monophasic S. Typhimurium (DT 193), only a single oral vaccination was carried out on day 1 of age (trial 6$)$. The animals of the vaccinated group $(n=16)$ and an unvaccinated control group $(n=16)$ were orally infected with $1 \times 10^{9}$ cfu per animal on day 17 of age ( $\triangleright$ Table 2 ). The quantification of the Salmonella challenge strain in the liver and cecal tissue (complete cecum without ingesta) was performed on days 24 and 31 .

Quantitative determination of the challenge strain content in liver and cecal mucosa

The quantification of the Salmonella challenge strains $\left(\log _{10} \mathrm{cfu} / \mathrm{g}\right)$ in the liver and cecal tissue was carried out using the plate counting method as previously described by Methner et al. [12]. In brief, the intestinal content was removed from the ceca. The livers, ceca (trials 1, 2 and 6) or cecal mucosa (trials 3-5) were respectively weighed and subsequently homogenized (Ultra-Turrax T25, Janke \& Kunkel, IKA ${ }^{\circledR}$-Labortechnik, Staufen, Germany). A 10-fold dilution series was prepared for enumeration of the Salmonella challenge strain of the processed organs. The number of bacteria was then estimated by spreading out the homogenate on deoxycholate citrate agar according to Leifson (Merck, Darmstadt, Germany) supplemented with antibiotics $(50 \mu \mathrm{g} / \mathrm{I}$ nalidixic acid [S. Typhimurium 421, S. Enteritidis PT1, 8 and 21]; $500 \mu \mathrm{g} / \mathrm{I}$ streptomycin [S. Infantis]; $50 \mathrm{mg} / \mathrm{l}$ ampicillin, $500 \mu \mathrm{g} / \mathrm{l}$ streptomycin, $100 \mathrm{mg} / \mathrm{I}$ sulfamera- zine and $10 \mathrm{mg}$ oxytetracycline [monophasic S. Typhimurium]). The incubation was performed at $37 \pm 1{ }^{\circ} \mathrm{C}$ for 24 hours under aerobic conditions. Samples which failed to grow were enriched in Rappaport Vassiliadis Broth (Merck, Darmstadt, Germany) at $37 \pm 1^{\circ} \mathrm{C}$ for 24 hours and spread on the above-mentioned agar. Samples that were only positive after enrichment received a $\log _{10}=1$. Samples that showed no growth received a $\log _{10}=0$. The mean and standard deviation were calculated for each group. Statistical evaluation was performed using the Mann-Whitney U-test (level of significance $p<0.05$ ) (GraphPad Prism version 8.4.3 for Windows, GraphPad Software, San Diego, California USA, www.graphpad.com).

\section{Serological testing}

Serum was obtained after centrifugation of blood samples for 10 minutes and $3500 \times g$ at $2-8^{\circ} \mathrm{C}$. For the detection of Salmonella-specific antibodies (group D), serum samples were tested using a commercially available ELISA kit (Chicken Salmonella Antibody Test Kit Group D, BioChek, Reeuwijk, The Netherlands) according to the manufacturer's instructions. Results were recorded as sample to positive $(S / P)$ ratios determined by the ratio between the mean optical density (OD) of each sample and the mean OD of the positive control.

\section{Results}

\section{Invasion inhibition effect}

Post infection, the challenge strains were isolated in the liver and cecal tissue of the control groups. In the vaccinated groups, the corresponding challenge strain was only detected in the cecal tissue. However, clinical signs were not observed in any chicken. The results of quantitative bacteriological examination of the liver and cecal tissue of the vaccine and control group animals are shown in $>$ Table 3. After infection with S. Typhimurium, significantly lower bacterial counts were found in the livers of the vaccine group animals compared to the control group chicks ( $8 \mathrm{dpc}$, $p=0.0011)$ in addition to the cecal tissue $(4 \mathrm{dpc}, \mathrm{p}=0.0465 ; 8 \mathrm{dpc}$, 
- Table 4 Challenge strain content (mean $\log 10 \mathrm{cfu} / \mathrm{g}$ ) in the liver and cecal tissue after challenge (testing of the immunogenicity).

- Tab.4 Infektionsstammgehalte in Leber und Blinddarmgewebe nach der Infektion (Prüfung der Immunogenität).

\begin{tabular}{|c|c|c|c|c|c|}
\hline \multirow[t]{2}{*}{ Trial } & \multirow[t]{2}{*}{ Group } & \multirow{2}{*}{$\begin{array}{l}\text { Challenge } \\
\text { strain }\end{array}$} & \multirow{2}{*}{$\begin{array}{l}\text { Day post } \\
\text { challenge }\end{array}$} & \multicolumn{2}{|c|}{ Challenge strain content (mean \pm SD) in $\log _{10} \mathrm{cfu} / \mathrm{g}$} \\
\hline & & & & Liver & Cecal tissue \\
\hline \multirow[t]{2}{*}{3} & Vaccinated & \multirow[t]{2}{*}{ SE PT8 } & 7 & $1.20 \pm 0.77^{a}$ & $6.05 \pm 0.42^{a}$ \\
\hline & Control & & 7 & $2.85 \pm 0.12$ & $6.96 \pm 0.50$ \\
\hline \multirow[t]{2}{*}{4} & Vaccinated & \multirow[t]{2}{*}{ SE PT21 } & 7 & $0.46 \pm 0.66^{a}$ & $5.41 \pm 0.71^{a}$ \\
\hline & Control & & 7 & $1.48 \pm 0.66$ & $6.26 \pm 0.63$ \\
\hline \multirow[t]{2}{*}{5} & Vaccinated & \multirow[t]{2}{*}{ SE PT1 } & 7 & $0.94 \pm 0.38^{a}$ & $5.42 \pm 0.84$ a \\
\hline & Control & & 7 & $2.34 \pm 0.45$ & $6.19 \pm 0.52$ \\
\hline \multirow[t]{4}{*}{6} & Vaccinated & \multirow[t]{4}{*}{ mSTM } & 7 & $1.19 \pm 0.59$ a & $6.78 \pm 0.28$ a \\
\hline & Control & & 7 & $2.06 \pm 0.26$ & $7.27 \pm 0.54$ \\
\hline & Vaccinated & & 14 & $0.12 \pm 0.35^{a}$ & $5.51 \pm 0.76^{a}$ \\
\hline & Control & & 14 & $0.75 \pm 0.46$ & $6.11 \pm 0.31$ \\
\hline
\end{tabular}

$p=0.0022$ ). Significantly lower invasion of the cecal tissue was also observed after infection with $S$. Infantis on $4 \mathrm{dpc}(\mathrm{p}=0.0055)$ and in both the liver and cecal tissue on $7 \mathrm{dpc}$ (liver: $p=0.0350$, ceca: $p=0.0006)$.

\section{Immunity against non-PT4 S. Enteritidis strains and monophasic S. Typhimurium}

After infection with the different phage types of $S$. Enteritidis and the monophasic S. Typhimurium strain, no symptoms associated with the infection were detected in the chickens.

The results of the mean $\log _{10} \mathrm{cfu} / \mathrm{g}$ of the challenge strain in liver and cecal tissue of the vaccine groups compared to the control groups after infection with the different $S$. Enteritidis phage types and the monophasic S. Typhimurium strain are shown in $\triangleright$ Table 4.

The mean $\log _{10} \mathrm{cfu} / \mathrm{g}$ of the challenge strain in liver and cecal tissue of the vaccinated animals was significantly lower after infection with S. Enteritidis PT8 (liver: reduction $1.65 \log _{10}, p<0.0001$, cecal tissue: reduction $0.91 \log _{10}, \mathrm{p}=0.0003$ ), PT21 (liver: reduction $1.02 \log _{10}, p=0.0048$, cecal tissue: reduction $0.85 \log _{10}, p=0.0190$ ) and PT1 (liver: reduction $1.40 \log _{10}, \mathrm{p}<0.0001$, cecal tissue: reduction $0.77 \log _{10}, p=0.0325$ ) when compared to the controls.

After infection with the monophasic $S$. Typhimurium strain, significant differences in the number of the challenge strain bacteria in liver and cecal tissue were found in vaccinated chickens compared to the controls on both $7 \mathrm{dpc}$ (liver: reduction $0.87 \log _{10}, \mathrm{p}<0.001$, cecal tissue: reduction $0.49 \log _{10}, p=0.023$ ) and $14 \mathrm{dpc}$ (liver: reduction $0.63 \log _{10}, p=0.020$, cecal tissue: reduction $0.60 \log _{10}$, $\mathrm{p}=0.032$ ).

The results of the serological examination after vaccination and challenge with S. Enteritidis PTs 1, 8 and 21 are shown in > Fig. 1. Immediately before the challenge and on day 7 after the challenge (day of necropsy), higher antibody titers occurred in the vaccine groups than in the corresponding control groups. Before challenge with S. Enteritidis PT1 (trial 5), the difference was found to be signif- icant $(p=0.0065)$. At necropsy significant differences $(p=0.0047)$ occurred after challenge with S. Enteritidis PT8 (trial 3). Overall, the vaccination only resulted in a negligible increase in antibody titers. A total of only 2 out of 48 vaccinated animals (all 3 trials together) showed antibodies above the cut off ( $S P \geq 50 \%$ ) before the challenge.

\section{Discussion}

After infection with Salmonella wild-type strains, phagocytes of the intestinal mucosa release reactive oxygen intermediates (ROI). According to Sterzenbach et al. [13] these processes are directed against the invasion of the pathogen and are an expression of innate immunity. Optimally, live vaccines should also induce ROI, which are directed against invasion of infectious strains after early infection. However, studies confirming these assumptions are currently lacking.

Braukmann et al. [5] showed an influx of neutrophils and macrophages into the lamina propria of the cecal mucosa after vaccination of day-old chicks with an attenuated SE-LV (Salmovac SE, Ceva Santé Animale, Libourne, France). This was associated with a strong elevated transcription of the pro-inflammatory mediators iNOS, IL-1 1 , LITAF, and IL12 which led to an inhibition of invasion and short-term inhibition of colonization after challenge with a S. Enteritidis wild-type strain.

In the present study, the invasion-inhibition effect could also be demonstrated after infection with S. Typhimurium and S. Infantis. Eeckhaut et al. [14] showed an invasion-inhibition effect against S. Enteritidis and S. Infantis after vaccination with a combined S. Enteritidis/S. Typhimurium live vaccine. After vaccination with a S. Enteritidis live vaccine alone, this effect was not present. Only both vaccines in combination showed a significant reduction of colonization of ceca (tissue and content) after infection with S. Enteritidis but not after infection with S. Infantis. In comparison to the re- 


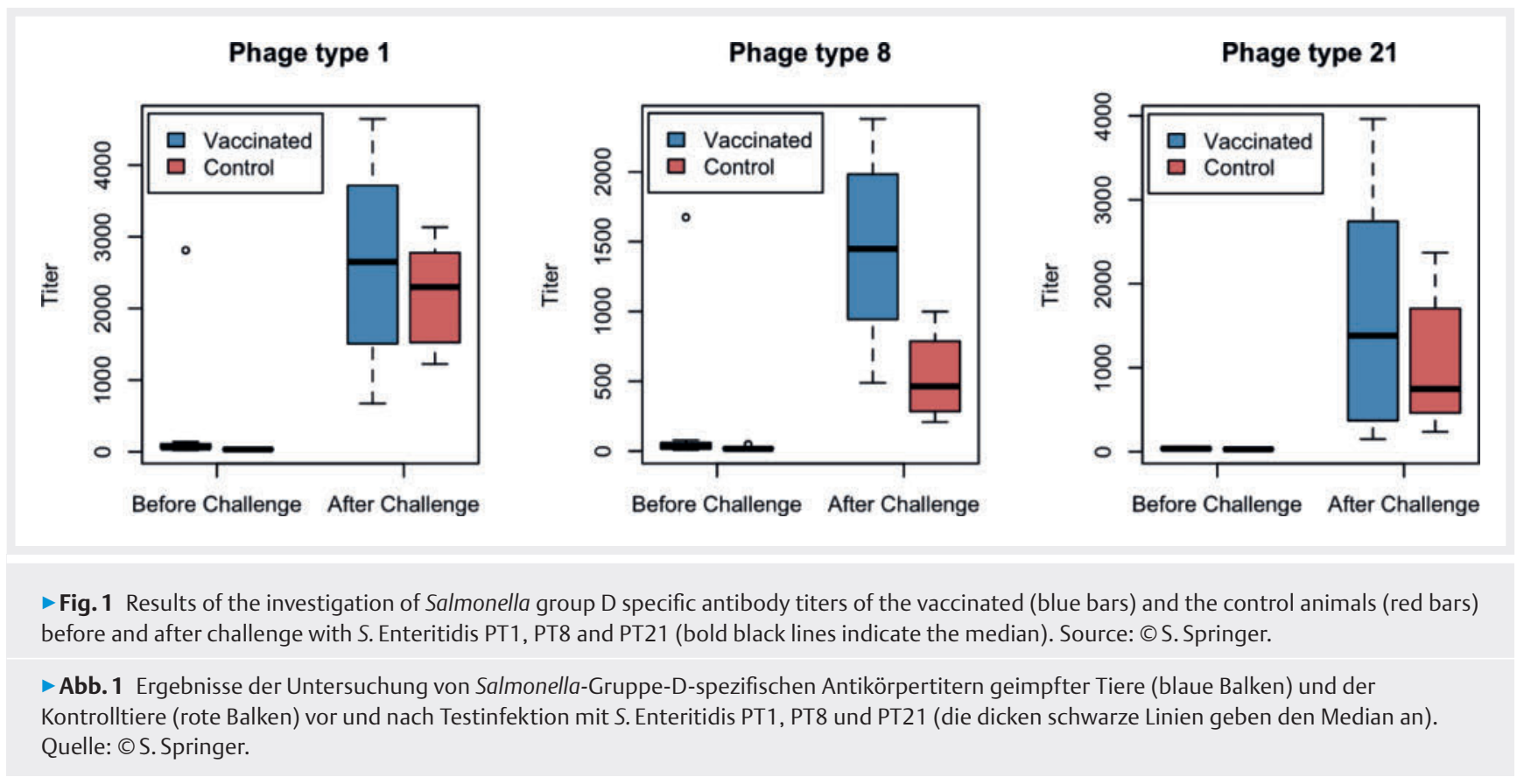

sults of Eeckhaut et al. [14] the results of this study imply that the extent of attenuation of the vaccine strain and possibly synergistic effects (live vaccines containing different vaccine strains) may have an influence on the invasion of S. Enteritidis and other Salmonella serovars. It is generally accepted that the reduction of colonization of the cecal mucosa is best achieved between isogenic Salmonella strains or Salmonella strains of the same serovar [15][16].

The present study demonstrates that a reduction of invasion of the cecal mucosa by S. Typhimurium and S. Infantis wild-type strains occurs also after immunization with SE-LV. The challenge strain used [16] and certainly the vaccination and infection doses can influence these effects. To compare our results with those of Braukmann et al. [5], how long these effects last and what significance they have for the field should be further examined.

The evidence of an adaptive immune response against $S$. Enteritidis PT4 after vaccination with a SE-LV (Salmovac SE, Salmovac 440, both Ceva Santé Animale, Libourne, France) was demonstrated with quantitative challenge models by Martin et al. [17], Springer et al. [9][18], Atterbury et al. [19] and Methner [7]. Furthermore, Theuß et al. [10] showed the efficacy of the vaccine after challenge with a S. Enteritidis PT4 strain according to the qualitative method described in the European Pharmacopoeia monograph 04/2013:2520.

In this study, immunity after vaccination with the SE-LV was also shown against PT1, 8 and 21 of S. Enteritidis. The differences in the quantification of the challenge strain in liver and cecal tissue between the vaccinated and the control group correspond to the results of Springer et al. [18] after infection with virulent S. Enteritidis PT4 strains.

Effects of cross-protection against $S$. Typhimurium have been demonstrated by Springer et al. [9] and for another SE-LV by Nandre et al. [20]. Results of this study show that a significant reduction of invasion of cecal tissue and liver also occurred after infection with a monophasic S. Typhimurium strain (DT 193). A direct comparison with the above-mentioned examinations is not possible, as the trials differ in the number of vaccinations and/or the infection model used.

Arnold et al. [21] demonstrated a reduction of eggshell contamination after infection with S. Enteritidis (PT14b), a biphasic S. Typhimurium strain (DT 8) and monophasic S. Typhimurium strains after vaccination with inactivated and live vaccines based on S. Enteritidis and S. Typhimurium, as well as by combinations of live and inactivated vaccines. However, they could not show a significantly reduced excretion of the challenge strains, measured by the number of Salmonella positive cloacal swabs, independently from the different vaccination regimen. This contrasts with the results of Theuß et al. [10], showing a significant and relevant reduction of the number of positive cloacal swabs after threefold vaccination with a SE-LV.

An unequivocal conclusion to this question is not possible because so many factors can influence the excretion rate including the vaccine and vaccination schedule, the challenge strain, the challenge dose, and individual animal factors. Nevertheless, Arnold et al. [21] recommend the use of vaccination against S. Enteritidis, S. Typhimurium and monophasic $S$. Typhimurium strains. As the contamination of the eggshells also depends on other factors [22] the use of vaccines should always be combined with veterinary hygiene measures like cleaning and disinfection in addition to rodent control.

The animals used to demonstrate immunogenicity against the S. Enteritidis non-PT strains in this trial were Salmonella negative and kept under isolated conditions. Thus it can be assumed that the Salmonella group D specific antibodies detected are antibodies against $S$. Enteritidis. The increase of the specific antibody titers after vaccination with the SE-LV and subsequent challenge with virulent S. Enteritidis strains corresponds to reports from Methner [7], Springer et al. [9] and Theuß et al. [10]. The increase after vaccination is usually much lower than after infection. This is most likely related to the attenuation of the vaccine strain. 


\section{CONCLUSION FOR PRACTICE}

As chicks are hatched without any substantial gut flora, they are very susceptible to Salmonella infections in their first few days of life. The results of this study demonstrate that vaccination with a Salmonella Enteritidis live vaccine provides early and not exclusively homologous protective effects. As Salmonella Enteritidis non phage type 4 strains and monophasic Salmonella Typhimurium strains are increasingly important in laying hen farms, the demonstration of immunogenicity against these variants after vaccination with a live Salmonella Enteritidis phage type 4 vaccine is of increased relevance for the field.

\section{Conflict of interest statement}

The authors are employed by Ceva Santé Animale, which distributes the S. Enteritidis live vaccines Salmovac SE and Salmovac 440. The content or opinions expressed in the manuscript have not been influenced by any proprietary, financial, professional or other personal interests.

\section{Acknowledgements}

We would like to thank the employees of Ceva Innovation Center $\mathrm{GmbH}$ (Germany) and Ceva Phylaxia Veterinary Biologicals co. Ltd (Hungary) for their excellent technical assistance. We would also like to thank Dr. Ulrich Methner (Friedrich Loeffler Institute, Jena, Germany) and Dr. Wolfgang Rabsch (Robert Koch Institute, National Reference Centre for Salmonella and other bacterial enteritis pathogens, Wernigerode, Germany) for providing the challenge strains. Dr. Tyson Eucker is gratefully acknowledged for reviewing the language of the manuscript.

\section{References}

[1] Anonymous. The European Union One Health 2018 Zoonoses Report. EFSA Journal 2019; 17 (12): 5926. doi:10.2903/j.efsa.2019.5926

[2] Collard JM, Bertrand S, Dierick K et al. Drastic decrease of Salmonella Enteritidis isolated from humans in Belgium in 2005, shift in phage types and influence on foodborne outbreaks. Epidemiol Infect 2008; 136 (6): 771-781

[3] Dallman T, Inns T, Jombart T et al. Phylogenetic structure of European Salmonella Enteritidis outbreak correlates with national and international egg distribution network. Microb Genom 2016; 2 (8): e000070. doi:10.1099/mgen.0.000070

[4] Lillehoj EP, Yun CH, Lillehoj HS. Vaccination against the avian enteropathogens Eimeria, Cryptosporidium and Salmonella. Anim Health Res Rev 2000, 1: 47-65

[5] Braukmann M, Barrow PA, Berndt A et al. Combination of competitive exclusion and immunisation with a live Salmonella vaccine in newly hatched chickens: Immunological and microbiological effects. Res Vet Sci 2016; 107: 34-41

[6] Cooper GL, Venables LM, Woodward MJ et al. Invasiveness and persistence of Salmonella enteritidis, Salmonella typhimurium, and a genetically defined S. enteritidis aroA strain in young chickens. Infect Immun 1994; 62 (11): 4739-4746

[7] Methner U. Immunisation of chickens with live Salmonella vaccines Role of booster vaccination. Vaccine 2018; 36 (21): 2973-2977

[8] Hassan JO, Curtiss R 3rd. Effect of vaccination of hens with an avirulent strain of Salmonella typhimurium on immunity of progeny challenged with wild-Type Salmonella strains. Infect Immun 1996; 64 (3): 938-944

[9] Springer $\mathrm{S}$, Lindner $\mathrm{T}$, Ahrens $\mathrm{M}$ et al. Duration of immunity induced in chickens by an attenuated live Salmonella enteritidis vaccine and an inactivated Salmonella enteritidis/typhimurium vaccine. Berl Munch Tierarztl Wochenschr 2011; 124: 89-93

[10] Theuß T, Woitow G, Bulang et al. Demonstration of the efficacy of a Salmonella Enteritidis live vaccine for chickens according to the current European Pharmacopoeia Monograph. Heliyon 2018; 4 (12): e01070. doi:10.1016/j.heliyon.2018.e01070

[11] Trüpschuch S, Laverde Gomez JA, Ediberidze I et al. Characterisation of multidrug resistant Salmonella Typhimurium 4,[5],12:i- DT193 strain carrying a novel genomic island adjacent to the thrW tRNA locus. Int J Med Microbiol Suppl 2010; 300: 279-288

[12] Methner U, Koch H, Meyer $\mathrm{H}$. Model for experimental efficacy testing of control measures against Salmonella infections in poultry. Dtsch Tierarztl Wochenschr 1995; 102 (6): 225-228

[13] Sterzenbach T, Crawford RW, Winter SE et al. Salmonella Virulence Mechanisms and their Genetic Basis. In: Barrow PA, Methner U, eds. Salmonella in Domestic Animals. Oxfordshire, Boston: CAB International; 2013: 86-87

[14] Eeckhaut V, Haesebrouck F, Ducatelle R et al. Oral vaccination with a live Salmonella Enteritidis/Typhimurium bivalent vaccine in layers induces cross-protection against cecal and internal organ colonization by a Salmonella Infantis strain. Vet Microbiol 2018; 218: 7-12

[15] Methner U, Barrow PA, Berndt A. Induction of a homologous and heterologous invasion-inhibition effect after administration of Salmonella strains to newly hatched chicks. Vaccine 2010; 28: 6958-6963

[16] Methner U, Haase A, Berndt A et al. Exploitation of intestinal colonization-inhibition between salmonella organisms for live vaccines in poultry - potential and limitations. Zoonoses Public Health 2011; 58: 540-548

[17] Martin G, Methner U, Steinbach G et al. Immunization with potential Salmonella enteritidis mutants -2 . Investigations on the attenuation and immunogenicity for mice and young hens. Berl Munch Tierarztl Wochenschr 1996; 109 (10): 369-74

[18] Springer S, Lehmann J, Lindner T et al. A new live Salmonella enteritidis vaccine for chickens - experimental evidence of its safety and efficacy. Berl Munch Tierarztl Wochenschr 2000; 113 (6): 246-252

[19] Atterbury RJ, Carrique-Mas J, Davies RH et al. Salmonella colonization of laying hens following vaccination with killed and live attenuated commercial Salmonella vaccines. Vet Rec 2009; 165 (17): 493-496

[20] Nandre RM, Lee D, Lee JH. Cross-protection against Salmonella Typhimurium infection conferred by a live attenuated Salmonella Enteritidis vaccine. Can J Vet Res 2015; 79: 16-21

[21] Arnold E, Gosling R], La Ragione RM et al. Estimation of the impact of vaccination on faecal shedding and organ and egg contamination for Salmonella Enteritidis, Salmonella Typhimurium and monophasic Salmonella Typhimurium. Avian Pathol 2014; 43 (2): 155-163

[22] Denagamage T, Jayarao B, Patterson P et al. Risk factors associated with Salmonella in laying hen farms: systematic review of observational studies. Avian Dis 2015; 59 (2): 291-302 